\title{
Application of medical equipment procurement data mining using the Apriori method
}

\author{
Phindika $^{1)^{*}}$, Yopi Handrianto ${ }^{2)}$, Sulaeman Hadi Sukmana ${ }^{3)}$ \\ ${ }^{1) 3}$ STMIK Nusa Mandiri, Indonesia, ${ }^{2}$ Bina Sarana Informatika University, Indonesia \\ ${ }^{1)}$ pindhika22@gmail.com, ${ }^{2}$ yopi.yph@bsi.ac.id ${ }^{3)}$ sulaeman.sdu@ nusamandiri.ac.id
}

Submitted : Feb 13, 2021 | Accepted : Mar 21, 2021 | Published : Apr 1, 2021

\begin{abstract}
The procurement of an item in an agency is an activity that is commonly carried out, including in a hospital, particularly the procurement of medical equipment. The procurement of medical equipment at Pengayoman Cipinang Hospital, Jakarta currently still uses the conventional method where the process is still using the manual method, namely by relying on disposable physical items as the main resource and seems to use many procedures that require a long working time. The influx of medical equipment in very large numbers can cause many risks, such as the amount of money it costs to store medical devices and also being vulnerable to the risk of theft. The conditions mentioned above can affect the quality of health services provided by the hospital to patients who should be well preserved. One of the data processing algorithms that is often used in the data mining process is the Apriori algorithm. The benefit is to find trends between one item and another, where more and more medical equipment appears to be used as a reference in the hospital policy process in ensuring the availability of this medical equipment when needed so that the procurement process can always be fulfilled. Based on the results of the research conducted, it was found that the medical equipment that had the most demand was Surgical Ear Loop Masks 3 (58.33\%), Non-Sterile Gloves Size M (58.33\%) and Surgical Tie On 3 PLY Masks (100\%).
\end{abstract}

Keywords: Apriori Algorithm, Data Mining, Hospital, Medical Equipment

\section{INTRODUCTION}

Based on the law, the hospital must meet several requirements such as location, building, infrastructure, human resources, infrastructure and equipment. Equipment in the law includes medical and non-medical equipment which must meet service standards, quality requirements, safety, safety and usability (Kepres, 2009).

A hospital is a health institution that organizes complete individual health services that provide inpatient, outpatient and emergency services, where when the hospital must provide professional, quality and sustainable health services, the hospital needs to be supported by the existence of medical devices that meet standards This equipment consists of medical equipment for emergency departments, outpatient care, inpatient care, intensive care, surgery care, childbirth, radiology, clinical laboratories, blood services, medical rehabilitation, pharmacy, nutrition installation and mortuary (Kenedi et al., 2018).

Procurement of goods in an agency is needed to support operational activities that occur. Likewise in hospital institutions such as Pengayoman Cipinang Hospital, East Jakarta, where the procurement of medical devices is needed carefully and precisely to support operational activities in serving patients. For the procurement of medical devices and medical equipment in a very large number, it is well calculated to have several risks, for example, a large enough space is required to store the medical equipment that has been purchased so that this creates vulnerability to medical conditions such as damage to the equipment because it has passed the safety limit. use, there is an excess of the need for the goods than it should be and the risk of medical robbery or embezzlement by irresponsible people (Afif et al., 2019). Thus, the availability of effective medical equipment can affect the quality of health services performed by the hospital.

One of the data processing algorithms that is often used in the data mining process is the apriori algorithm. The benefit is to find trends between one item and another, where more and more medical equipment appears to be used as a reference in the hospital policy process in ensuring the availability of this medical equipment when needed so that the medical equipment procurement process can always be fulfilled. Data mining using apriori algorithms can be used to analyze and determine the procurement of drugs and medical equipment (Yanto \& Khoiriah, 2015).

*name of corresponding author 


\section{Data Mining}

\section{LITERATURE REVIEW}

According to Turban, concluded that data Mining is a process that uses statistical, mathematical, artificial intelligence and machine learning techniques to extract and identify useful information and related knowledge from various large database (Nofriansyah, 2015). Research from (Badrul, 2015), data mining is used in grouping data for legislative candidates using the K-Nearest Neighbor Method in the DKI Jakarta legislative elections where the results of these predictions can be used by parties related to the election activities being carried out. The research (Luvia et al., 2016) described grouping student data at a university into data mining to determine the predicate of student success based on several criteria using the C.45 Algorithm Method so that it makes it easier for universities to predict and classify student success predicates. According (Rismayanti et al., 2018) with the same method, conducting research on the application of data mining to determine the track record of lecturer performance with the attributes set to provide information on the results of lecturer performance evaluations in implementing the Tri Dharma of Higher Education. In (Anas, 2016) describes research related to data mining which classifies data from students who borrow books from the library based on their tendency to appear simultaneously in a book lending activity using the Apriori Algorithm. This research hopes that the school can determine the procurement and placement of books in the library. Research with the same algorithm was carried out (Irfiani, 2019) in determining the patterns and strategies of selling products that are of interest to consumers so as to reduce the number of product stocks that consumers are less interested in. (Santoso et al., 2016) conducted a research on the application of data mining to analyze product purchase patterns at a supermarket using the a priori algorithm to determine consumer behavior while shopping for products simultaneously, as an alternative decision making to determine the placement of products whose positions are close to each other according to consumer behavior when shopping for products simultaneously. According to (Gunadi \& Sensuse, 2012) the fact that data mining is a data analysis process to find a data pattern. The data mining technique used in this research is association data mining or market basket analysis. By using the Apriori Algorithm and FP-Growth, a number of related rules are found from the basic data of sales transactions for book products that are sold so that they can be used by management for consideration in making effective marketing and sales strategies. Some of the research that has been done above, in particular the application of data mining using the apriori algorithm method can be used to conduct research in hospitals for the procurement of medical equipment so that trends can be seen between one item and another, where more and more medical devices seem to be able to be used. reference in the hospital policy process in ensuring the availability of medical devices when needed so that the supply process can always be properly fulfilled.

According to Kusrini in (Listriani et al., 2016), stated that the basic methodology of association analysis consists of two, namely: analysis of high frequency patterns and the formation of associative rules.

\section{High Frequency Pattern Analysis}

This stage looks for combinations of items that meet the minimum requirements of the support value in the database. The value of an item's support is obtained by the following formula 1 .

$$
\text { Support }(A)=\frac{\text { Total Transaction Containing A }}{\text { Total Transaction }} * 100 \%
$$

While the support values of the 2 items are obtained from the following formula 2.

$$
\operatorname{Support}(\mathrm{A}, \mathrm{B}) \frac{\sum \text { Transaction Containing A and B }}{\sum \text { Transaction }} * 100 \%
$$

\section{Establishment of associative rules}

The formation of the association rules is done after all high frequency patterns have been found, then the association rules are found to meet the minimum requirements for confidence by calculating the associative rule confidence if A then B. The confidence value of the rule if A then B, is obtained from the following formula 3 .

$$
\text { Confidence }(\mathrm{A}, \mathrm{B})=\frac{\sum \text { Total Transaction Containing A and B }}{\sum \text { Total Transaction A }} * 100 \%
$$

\section{Apriori algorithm}

Apriori algorithms include types of association rules in Data Mining. Rules that state the association between several attributes are often called affinity analysis or market basket analysis (Rusdiansyah et al., 2020). Association analysis or association rule mining is a Data Mining technique to find the rules for a combination of items. The apriori algorithm is the basic algorithm proposed by Agrawal \& Srikant in 1994, which functions in 
determining a set of items that are often used as boolean association rules. This algorithm belongs to the type of association rule in data mining (Badrul, 2016).

In general, the steps of the apriori algorithm are is:

a. Formation of itemset candidates, $k$-itemset candidates are formed from a combination (k-1) -itemset obtained from the previous iteration. One feature of the Apriori algorithm is the pruning of $\mathrm{k}$-itemset candidates whose subsets containing k-1 items are not included in the high frequency pattern with k-1 length.

b. Calculation of support for each k-itemset candidate. Support from each k-itemset candidate is obtained by scanning the database to count the number of transactions containing all items in the k-itemset candidate. This is also a feature of the apriori algorithm which requires the calculation by scanning the entire database of the longest k-itemset.

c. Set high frequency pattern. High frequency patterns containing $\mathrm{k}$ items or k-itemset are determined from candidate $\mathrm{k}$-itemset whose support is greater than the minimum support. If the acquisition of new frequency patterns does not exist, the process being carried out can be terminated. If not, then $\mathrm{k}$ plus one and then return to part 1.

\section{Tanagra}

Tanagra is a data mining software developed for academic and research purposes that contains methods that can be applied in the fields of data analysis, statistics, machine learning and databases. Tanagra has the first goal of providing easy access to data mining software for researchers, teachers and students. Second, is to provide researchers with a buildable architecture to which they can add their own experimental algorithms and compare them with existing solutions until the theme supports the time it takes to implement implementation details and supports them to focus on data management. Lastly not the least being open source helps provide an overview of what data mining looks like so they can build their own if that is their interest (Rocha et al., 2016).

\section{METHOD}

The following is the research methodology used in the research conducted by the author.

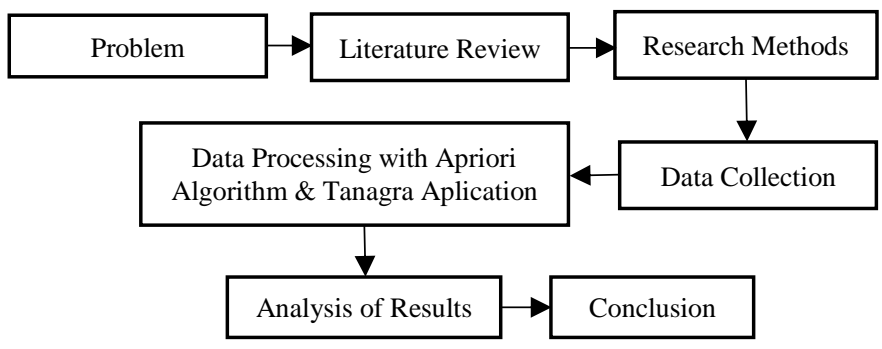

Fig. 1 Research Stages

\section{Data Collection Methods, Population and Research Samples \\ Method of Collecting Data}

Data collection for this research was carried out in stages:

1. Observations. Observe directly at the equipment section at Pengayoman Cipinang Hospital such as carrying out activities for receiving entrance equipment, checking entry equipment and filing medical equipment taken by all parts of the hospital as needed.

2. Interview. There is direct communication with the medical equipment procurement department to obtain information from activities related to the procurement of medical equipment.

3. Literature review. Studying scientific journal literature and reference books to support research.

\section{Population and Sample Studies}

Population is a generalization area in the form of the subject or object under study and has the quality determined by the researcher for research to be drawn conclusions. Meanwhile, the sample is a part or a representation of the population so that the research results obtained from the sample can be generalized to the population (Sugiyono, 2015).

\section{Population and Sample}

The population that became the object of this study were some of the dominant medical equipment needed at Pengayoman Hospital with a total of 12 products. 
Table 1

Population

\begin{tabular}{cc}
\hline Medical Equipment Required & Amount \\
\hline 12 & 12 \\
\hline
\end{tabular}

The sample that will be used to determine the medical equipment that will be needed is 12 products. This study uses nonprobability sampling, there are several types of samples in this study, the sample used for products that are sold simultaneously is saturated samples.

Table 2

Medical Equipment Samples

\begin{tabular}{cl}
\hline No & Medical Equipment Samples \\
\hline 1 & Surgical Tie On Mask 3 PLY \\
2 & Non Sterile Gloves Size L \\
3 & Non Sterile Gloves Size M \\
4 & Ear Loop Surgical Mask 3 \\
5 & Non Sterile Gloves Size S \\
6 & Mask N 95 \\
7 & Zalfa Alcohol Swab \\
8 & Plastic Gloves \\
9 & Tissue Rolls \\
10 & Alcohol 70\% 1 Liter \\
11 & Nebulizer Mask \\
12 & Caviton \\
13 & Patient Clothes \\
14 & Water for Injection 25ml \\
15 & Lidocain Injection \\
16 & Meylon 8.4\% 25ml Infusion \\
17 & D 5\% Liquid \\
18 & D10\% Liquid \\
19 & Hand Tissue Towel \\
20 & Paseo Tissue Soft \\
\hline & \\
\hline
\end{tabular}

\section{Data Analysis Method}

\section{High Frequency Pattern Analysis}

This stage looks for a combination of items that meet the minimum requirements of the support value in the database. The support value of an item is obtained by the following formula 1 :

$$
\text { Support }(A)=\frac{\Sigma \text { Transaction containing A }}{\Sigma \text { Transaksi }} * 100 \%
$$

The support value of 2 items is obtained from the following formula 2 : Support $(A, B)=P(A \cap B)$

$$
\text { Support }(A, B)=\frac{\Sigma \text { Transaction containing } \mathrm{A}, \mathrm{B}}{\Sigma \text { Transaction }} * 100 \%
$$

Meanwhile, the support value of 3 items is obtained from the following formula 3 :

$$
\text { Support }(A, B \text {, and } C)=\frac{\Sigma \text { Transaction containing } \mathrm{A}, \mathrm{B} \text { and } \mathrm{C}}{\Sigma \text { Transaction }} * 100 \%
$$


The formation of the association rule after all high frequency patterns are found, then we look for an associative rule that meets the minimum requirements for confidence by calculating the associative rule A - B The confidence value of rules $\mathrm{A}$ - B is obtained from the following formula :

$$
\text { Confidence }=P(A \mid B)=\frac{\sum \text { Transaction containing } \mathrm{A} \text { and } \mathrm{B}}{\sum \text { Transaction } \mathrm{A}}
$$

\section{Analysis Using the Apriori Algorithm Method}

\section{RESULT}

Apriori algorithms are commonly used to find association rules that meet the minimum requirements of support and confidence, which is the strength of the relationship between items in the association rule.

\section{Establishment of 1 itemset}

The process of completing the formation of 1 itemset or $\mathrm{C}_{1}$ with a support amount of $25 \%$ with the formula :

$$
=\frac{\Sigma \text { Transaction containing A }}{\Sigma \text { Transaction }} * 100 \%
$$

Table 3

1 Itemset

\begin{tabular}{lcc}
\hline \multicolumn{1}{c}{ Itemset } & Amount & Support \\
\hline Surgical Tie On Mask 3 PLY & 12 & $100 \%$ \\
\hline Ear Loop Surgical Mask 3 & 7 & $58,33 \%$ \\
\hline Non Sterile Gloves Size M & 7 & $58,33 \%$ \\
\hline Mask N 95 & 3 & $25 \%$ \\
\hline
\end{tabular}

\section{Establishment of 2 itemset}

The process of completing the formation of 2 itemset or $\mathrm{C}_{2}$ with a minimum amount of support of $25 \%$ with the formula :

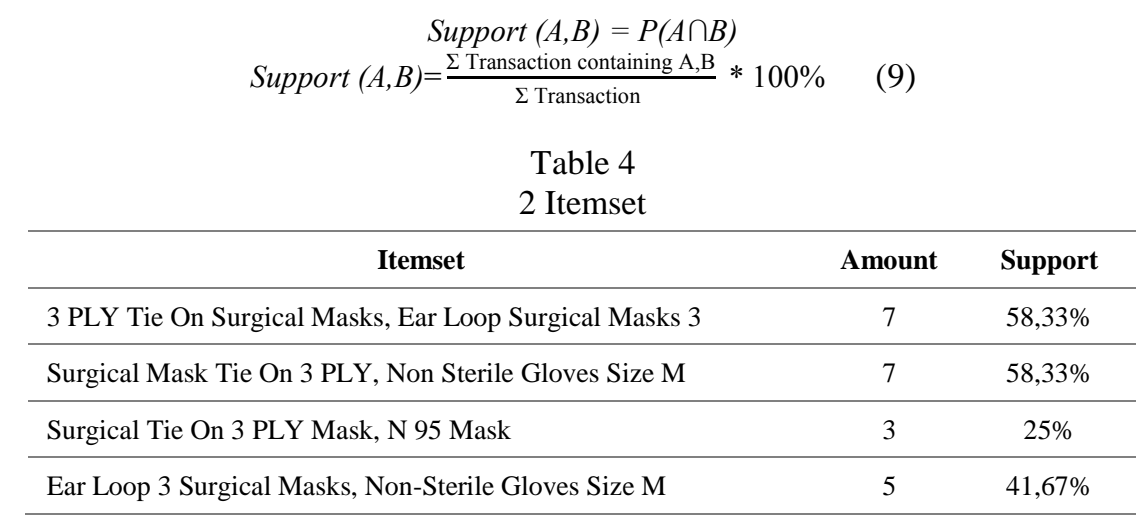

\section{Establishment of Association Rules}

After all high frequency patterns are found, then calculate the association rule with at least $50 \%$ confidence with the formula:

$$
\text { Confidence }=P(A \mid B)=\frac{\Sigma \text { Transaction containing A and B }}{\Sigma \text { Transaction A }} * 100 \%
$$

Table 5

Candidates for Association Rules

\begin{tabular}{lcc}
\hline \multicolumn{1}{c}{ Itemset } & Confidence \\
\hline $\begin{array}{l}\text { If you buy a Surgical Ear Loop 3 Mask, Non-Sterile Gloves Size M, you will } \\
\text { buy a Surgical Tie On 3 PLY Mask. }\end{array}$ & $5 / 12$ & $41,67 \%$ \\
\hline $\begin{array}{l}\text { If you buy Ear Loop 3 Surgical Masks, you will buy Non Sterile Gloves Size M, } \\
\text { Surgical Tie On 3 PLY Masks. }\end{array}$ & $5 / 7$ & $71,43 \%$ \\
\hline
\end{tabular}


If you buy a Surgical Tie On 3 PLY Mask, 3 Ear Loop Surgical Masks, you will buy a Non Sterile Size M Gloves.

$5 / 7 \quad 71,43 \%$

\section{Final Association Rule}

The final association rules are obtained from the percentage value that meets the requirements, namely a predetermined minimum of support and confidence. The items in question are listed in the following table,

Table 6

Final Association

\begin{tabular}{lcc}
\hline \multicolumn{1}{c}{ Itemset } & Support & Confidence \\
\hline $\begin{array}{l}\text { If you ask for a Surgical Ear Loop 3 Mask, you will ask for Non-Sterile Size M } \\
\text { Gloves and a Surgical Tie On 3 PLY Mask }\end{array}$ & 41,67 & 71,43 \\
\hline $\begin{array}{l}\text { If you ask for Size M Non-Sterile Gloves, you will ask for a Surgical Tie On 3 } \\
\text { PLY Mask and a Surgical Ear Loop 3 Mask }\end{array}$ & 41,67 & 71,43 \\
\hline
\end{tabular}

Based on the final association rules that have been generated in the table above, it can be seen that medical equipment that is often used or issued for requests from the hospital medical department can be seen in the following graph,

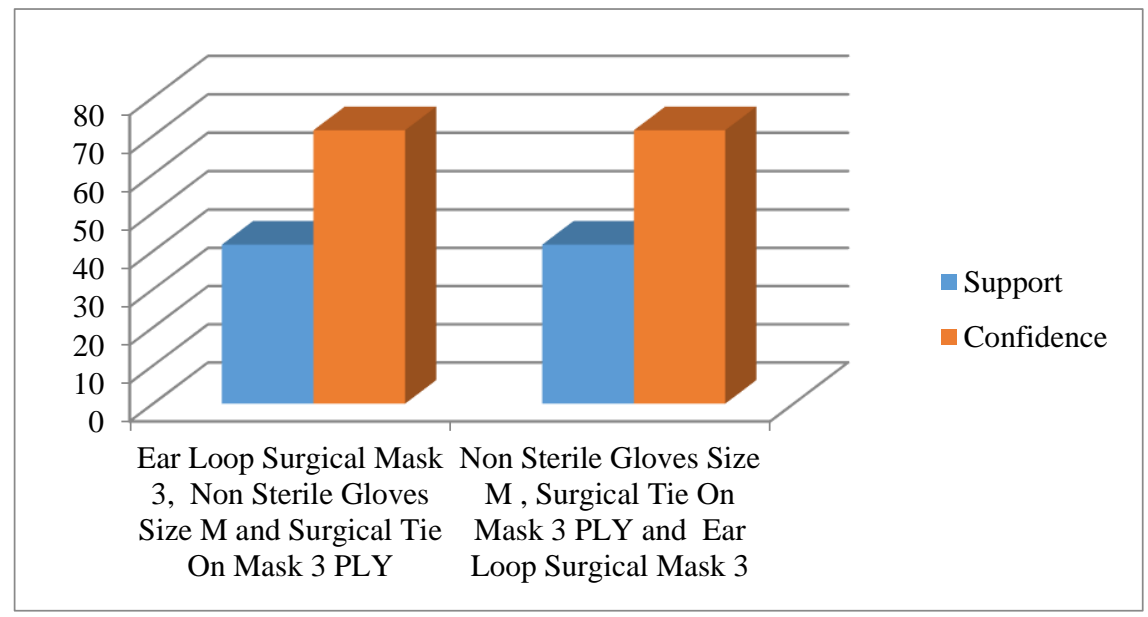

Fig. 2 Final Association Rules Formation Result Diagram

Based on the chart above, the most requested medical supplies are Surgical Ear Loop 3 Masks, Size M NonSterile Gloves and Tie On 3 PLY Surgical Masks. By knowing the medical equipment that is most in demand by the medical department, the hospital can use it as basic information in developing a demand strategy by providing information to anticipate the void of medical equipment for future procurement.

\section{Calculation with Tanagra}

\section{DISCUSSIONS}

The algorithm for determining support can be seen below which consists of input, output and process. Following are the results of calculations using Tanagra,

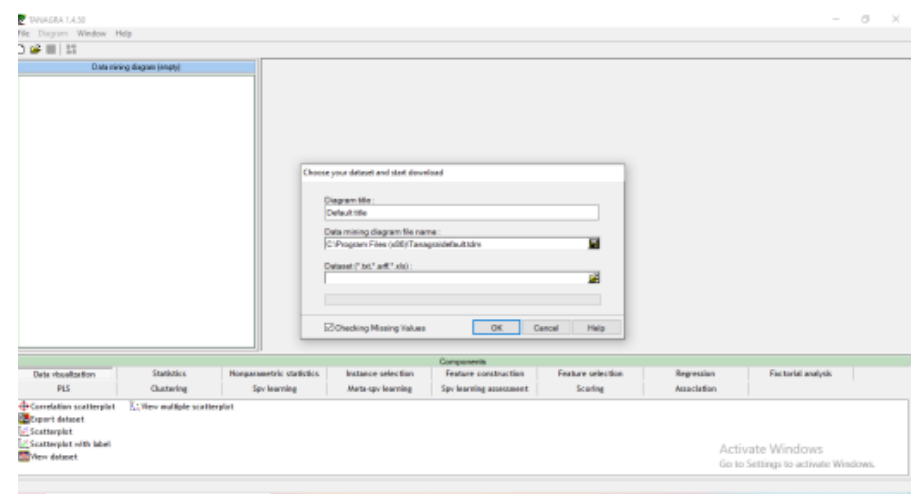

Fig. 3 Import File view 


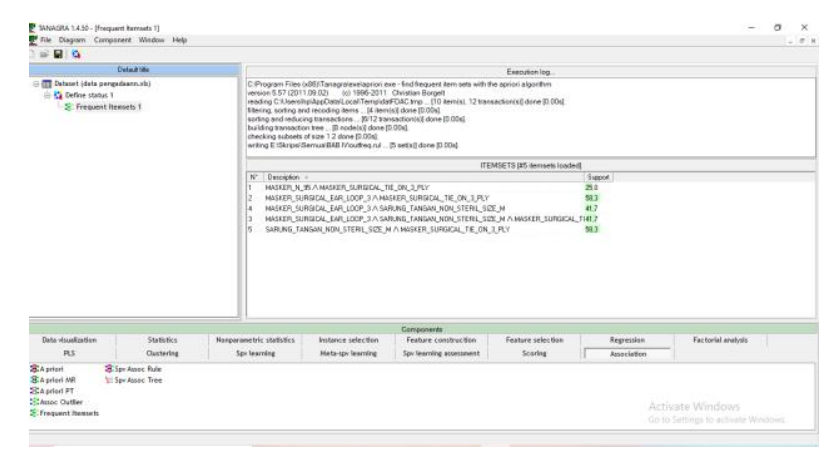

Fig. 4 View Frequent Itemset

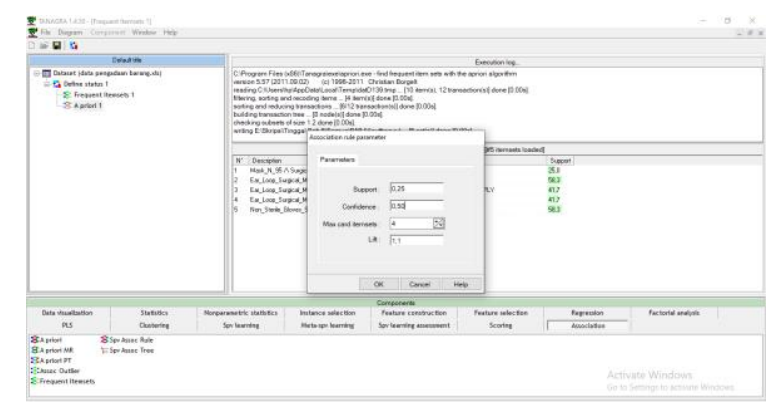

Fig. 5 Parameters Apriori

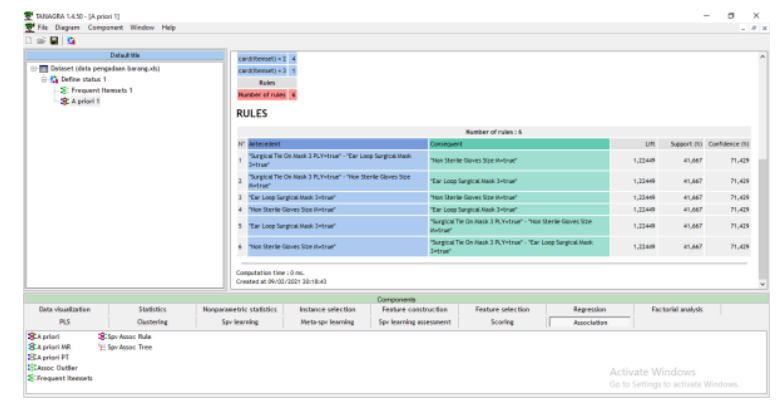

Fig. 6 Confidence Result

\section{CONCLUSION}

In the calculation using the apriori algorithm, the results of the most demanded medical equipment are Ear Loop 3 Surgical Masks, Non-Sterile Size M Gloves and Surgical Tie On 3 PLY Masks. From the final association rules, the first is if you ask for Ear Loop 3 Surgical Masks, you will ask for Non-Sterile Size M Gloves and Surgical Tie On 3 PLY Masks with a support value of $41.67 \%$ and a confidence value of $71.43 \%$ and the second if asking for Size M non-sterile gloves, you will ask for a Surgical Tie On 3 PLY Mask and a Surgical Ear Loop 3 Mask with a support value of 41.67 and a confidence value of 71.43. The Apriori algorithm can assist hospitals in developing a medical equipment procurement strategy by providing early information to anticipate vacancies in needed medical equipment.

\section{REFERENCES}

Afif, M., Ayu, D., \& Wulandari, N. (2019). Implement Of Apriorial Algorithm For Procurement Of Medicine And Helath Equipment On Radiology Departement Of Mayapada Hospital. 16(2), 99-104. https://ejournal.nusamandiri.ac.id/index.php/techno/article/view/737/561

Anas, A. (2016). Analisa Algorithma Apriori Untuk Mendapatkan Pola Peminjaman Buku Perpustakaan Smpn 3 Batanghari. Jurnal Ilmiah Media SISFO, 10(2), 628-641. http://ejournal.stikomdb.ac.id/index.php/mediasisfo/article/view/233/220

Badrul, M. (2015). Prediksi Hasil Pemilu Legislatif Dengan Menggunakan Algoritma K-Nearest Neighbor. Jurnal Pilar Nusa Mandiri, XI(2), 152-160. http://ejournal.nusamandiri.ac.id/index.php/pilar/article/view/424/374

Badrul, M. (2016). Algoritma Asosiasi Dengan Algoritma Apriori Untuk Analisa Data Penjualan. None, 12(2), 121-129. https://media.neliti.com/media/publications/227549-algoritma-asosiasi-dengan-algoritma-aprif4245cc8.pdf

Gunadi, G., \& Sensuse, D. I. (2012). Penerapan Metode Data Mining Market Basket Analysis Terhadap Data 
Penjualan Produk Buku Dengan Menggunakan Algoritma Apriori Dan Frequent Pattern Growth ( Fp$\begin{array}{llll}\text { Growth } \quad \text { Telematika, } & 4(1), & 118-132 .\end{array}$ https://journal.budiluhur.ac.id/index.php/telematika/article/view/164/158

Irfiani, E. (2019). Application of Apriori Algorithms to Determine Associations in Outdoor Sports Equipment Stores. SinkrOn, 3(2), 218. https://doi.org/10.33395/sinkron.v3i2.10089

Kenedi, J., Lanin, D., \& Agus, Z. (2018). Analisis Pengadaan Alat Kesehatan Di Rumah Sakit Umum Daerah Padang Pariaman Tahun 2017. Jurnal Kesehatan Andalas, 7(Supplement 2), 9. https://doi.org/10.25077/jka.v7i0.818

Kepres. (2009). Undang-Undang Republik Indonesia Nomor 44 Tahun 2009 (p. 41).

Listriani, D., Setyaningrum, A. H., \& Eka, F. (2016). Penerapan Metode Asosiasi Menggunakan Algoritma Apriori Pada Aplikasi Analisa Pola Belanja Konsumen (Studi Kasus Toko Buku Gramedia Bintaro). Jurnal Teknik Informatika, 9(2), 120-127. https://doi.org/10.15408/jti.v9i2.5602

Luvia, Y. S., Hartama, D., Windarto, A. P., \& Solikhun. (2016). Penerapan Algoritma C4.5 Untuk Klasifikasi Predikat Keberhasilan Mahasiswa di AMIK Tunas Bangsa. Jurnal Riset Sistem Informasi \& Teknik Informatika, https://www.researchgate.net/publication/315890951_Penerapan_Algoritma_C45_Untuk_Klasifikasi_Pred ikat_Keberhasilan_Mahasiswa_di_AMIK_Tunas_Bangsa/link/58ec6f51 aca272bd2876044f/download

Nofriansyah, D. (2015). Konsep Data Mining VS Sistem Pendukung Keputusan. Deepublish.

Rismayanti, R., Damayanti, F., \& Khairunnisa, K. (2018). Penerapan Data Mining Algoritma C4.5 dalam Menentukan Rekam Jejak Kinerja Dosen STT Harapan Medan. SinkrOn, 3(1), 99-104. https://doi.org/10.33395/sinkron.v3i1.173

Rocha, A., Correia, A. M., Adeli, H., \& Reis, L. P. (2016). New Advances in Information System and Technology (M. M. Teixeira (ed.); Vol. 1). Springer Nature.

Rusdiansyah, Suharyanti, N., Triningsih, \& Murniyati. (2020). Application Of Pizza Sales Data Mining Using Apriori Method. SinkrOn, 4(2), 1. https://doi.org/10.33395/sinkron.v4i2.10500

Santoso, H., Hariyadi, I. P., \& Prayitno. (2016). Data Mining Analisa Pola Pembelian Produk Dengan Menggunakan Metode Algoritma Apriori. Teknik Informatika, 1, 19-24. http://ejournal.stikomdb.ac.id/index.php/mediasisfo/article/view/233/220

Yanto, R., \& Khoiriah, R. (2015). Implementasi Data Mining dengan Metode Algoritma Apriori dalam Menentukan Pola Pembelian Obat. Creative Information Technology Journal, 2(2), 102. https://doi.org/10.24076/citec.2015v2i2.41 